\title{
Identifikasi Hama Penggerek Batang dan Deskripsi Kerusakan pada Tanaman Melina (Gmelina arborea)
}

\section{Identification of Stem Borer and Damage Characteristic on Melina (Gmelina arborea) Plantation}

\author{
Ananto Triyogo ${ }^{*}$, Sumardi ${ }^{1}$, dan Yohanes Andi Trisyono ${ }^{2}$ \\ ${ }^{1}$ Jurusan Budidaya Hutan, Fakultas Kehutanan UGM, Yogyakarta \\ ${ }^{2}$ Jurusan Hama dan Penyakit Tanaman, Fakultas Pertanian UGM, Yogyakarta \\ E-mail: triyogo99@ugm.ac.id *Penulis untuk korespondensi
}

\begin{abstract}
Gmelina arborea is one of the important trees for forest plantation. It is used for pulp, paper and plywood. Considering that $G$. arborea is an exotic type, this species has highly risk of receiving pest and diseases. This research was aimed to study the biological characteristics, attack pattern and distribution of stem borers. Studies were conducted in PT. Sumalindo (East Kalimantan). The sampling plot was $20 \times 20 \mathrm{~m}^{2}$, and the plants were stratified based on the plant age. Observations were directed to determine the species of stem borers and the damage they caused. Xyleutes ceramica and Acalolepta rusticatrix were documented attacking G. arborea, with their damage intensity of $13 \%$ and $54.8 \%$. These insect attacked $22 \%$ and $64.4 \%$ of the plant plantation.
\end{abstract}

Key words: G. arborea, stem borer, $X$. ceramica, $A$. rusticatrix

\begin{abstract}
Abstrak
Gmelina arborea adalah salah satu pohon penting untuk industri hutan tanaman. Pohon ini dapat digunakan sebagai bahan baku pembuatan pulp, kertas, dan plywood. Mengingat bahwa G. arborea adalah jenis eksotik, maka jenis ini memiliki resiko tinggi terserang hama dan penyakit. Penelitian ini bertujuan untuk mengetahui karakteristik biologi dan kerusakan yang diakibatkan oleh penggerek batang. Plot sample berukuran $20 \times 20 \mathrm{~m}^{2}$ dan tanaman dikelompokkan berdasarkan umur. Pengamatan diarahkan pada penentuan jenis penggerek batang serta tipe kerusakan yang disebabkan Xyleutes ceramica dan Acalolepta rusticatrix ditemukan menyerang $G$. arborea, dengan intensitas kerusakan masing-masing $13 \%$ dan $54,8 \%$. Adapun luas serangan masing-masing adalah sebesar 22\% dan 64,4\%.
\end{abstract}

Kata kunci: G. arborea, Hama Penggerek Batang, X. ceramica, A. rusticatrix

Diterima: 17 April 2009, disetujui: 03 Maret 2010

\section{Pendahuluan}

Teori yang berkembang menyatakan bahwa, hutan alam di daerah tropis memiliki karakteristik keanekaragaman tinggi, sedangkan hutan tanaman dicirikan dengan tanaman seumur, sejenis serta dipercaya rentan terhadap hama dan penyakit. Hutan tanaman dengan penyusun jenis-jenis eksotik telah berkembang dengan cepat dan dalam skala luas beberapa tahun terakhir (Dvorak dan Hodge, 1998). Namun, permasalahan akibat serangan hama dan penyakit secara berangsur-angsur muncul pada jenis eksotik yang digunakan untuk hutan tanaman, sehingga biaya pengelolaannya cenderung meningkat.

G. arborea merupakan jenis tanaman eksotik yang ditanam di Indonesia, merupakan jenis yang cepat tumbuh (fast growing species) serta mampu menghasilkan kayu keras yang cocok untuk bangunan, kerajinan, dan lainnya. Jenis ini juga dapat digunakan sebagai penghasil pulp dan kayu lapis dengan kualitas yang bagus. Pengusahaan hutan tanaman dalam skala luas di Indonesia telah dilakukan terutama di wilayah Sumatra, Riau, Jambi, dan Kalimantan. Informasi tentang serangga penggerek batang 
pada tanaman melina beserta deskripsi kerusakannya belum banyak dilakukan. Oleh karena itu, penelitian mengenai jenis-jenis penggerek batang pada tanaman melina perlu dilakukan. Hasil penelitian ini merupakan informasi mengenai hama serangga yang menjadi penggerek batang pada tanaman melina. Nair (1982) telah melaporkan serangan Sahyadrassus malabaricus (Lepidoptera: Hepialidae) pada tanaman melina. Lebih lanjut, Mathew (1986), Nair dan Mathew (1988) mengatakan bahwa serangan penggerek batang melina di India disebabkan oleh Xyleborus [Euwallacea] fornicatus (Coleoptera: Scolytidae). Di Burma, Wingfield dan Robinson (2003) menambahkan bahwa telah ditemukan beberapa jenis penggerek batang yang belum teridentifikasi dan belum pernah di laporkan secara resmi.

\section{Metode Penelitian}

Penelitian dilakukan di areal PT. Sumalindo, Kalimantan Timur. Mengambil lokasi pada compartment-compartment yang menggambarkan perbedaan umur tanaman melina. Petak ukur (PU) dengan ukuran 20 x 20 $\mathrm{m}$ diletakkan pada transek berukuran lebar $20 \mathrm{~m}$ dan jarak antartransek $100 \mathrm{~m}$ yang telah ditentukan dan diusahakan merata pada compartment yang diamati. Untuk dapat memberikan liputan terbaik dari petak yang ada, petak diletakkan dalam bentuk zig zag (McMaugh, 2007). Pengambilan data dilakukan disetiap compartment dengan intensitas sampling 2,5\% dan dengan petak ukur 0,04 ha berbentuk empat persegi panjang. Jumlah petak ukur di setiap compartment bervariasi antara 4-17 petak ukur.

Tabel 1. Skor tingkat serangan penggerek batang.

\begin{tabular}{lc}
\hline \multicolumn{1}{c}{ Gejala Serangan / Kondisi Pohon } & Skor \\
\hline \hline Sehat (tidak ada gejala serangan) & 0 \\
Terserang ringan (pohon terserang hama, terdapat 1-2 lubang gerek pada batang, tajuk tampak sehat) & 1 \\
Terserang sedang (pohon terserang hama, terdapat lebih dari 2 lubang gerek pada batang, tajuk & 2 \\
tampak sehat) & \\
Terserang berat (pohon terserang hama, terdapat lebih dari 2 lubang gerek pada batang, dan sebagian & 3 \\
kecil tajuk klorosis) & 4 \\
Terserang sangat berat (pohon roboh/batang patah atau sebagian besar tajuk klorosis) & 5 \\
Mati (seluruh daun layu atau rontok atau tidak ada tanda-tanda kehidupan) & \\
\hline \hline
\end{tabular}

\section{Koleksi Serangga}

Informasi tentang karakteristik dan informasi biologis hama penggerek batang diperoleh dengan melakukan koleksi imago dan larva hama penggerek yang ditemui di lapangan. Koleksi imago dilakukan dengan memasang langsung jaring pada lubang serangan. Imago morfologinya dan kedudukannya dalam taksonomi. Koleksi larva dilakukan langsung dari lapangan dengan menyayat bagian batang yang menunjukkan gejala terserang penggerek batang. Larva yang telah diperoleh, digunakan sebagai bahan rearing di laboratorium untuk mengetahui pertumbuhan dan perkembangannya.

\section{Parameter yang diamati}

\section{Intensitas Serangan Penggerek Batang}

Pengamatan dilaksanakan dengan melihat kenampakan fisik tanaman (batang dan tajuk) dengan melihat tingkat perkembangan gejala yang ada pada tiap-tiap bagian tanaman dan dilanjutkan menghitung intensitas dan luas serangan. Pengamatan gejala (lubang baru atau lama) dan tanda serangan dilakukan dengan menggunakan loupe, dilanjutkan pengukuran tinggi lubang gerekan dari permukaan tanah dengan menggunakan meteran, sedangkan luas serangan serta intensitas serangan dihitung dan di diskripsikan dengan melihat kondisi tanaman inang (Tabel 1).

\section{Analisis Data}

Perhitungan luas serangan serta intensitas serangan dihitung berdasarkan metode Cooke $e t$ al., (2006). yang diperoleh, diidentifikasi karakter 


\section{Hasil dan Pembahasan}

\section{Jenis Penggerek Batang}

Dua jenis penggerek batang telah ditemukan menyerang pertanaman G. arborea, yaitu:

\section{Xyleutes ceramica}

Penggerek pertama yang ditemukan adalah X. ceramica (Noerdjito, 2004), termasuk dalam bangsa Lepidoptera dengan susunan taksonomi sebagai berikut (Borror et al., 2002):

Bangsa : Lepidoptera

Suku : Cossidae

Species: Xyleutes ceramica

\section{Larva}

Larva muda ditandai dengan adanya bagian tubuh yang berwarna ungu dan warna ini akan semakin memudar mengikuti bertambahnya umur larva. Larva dewasa umumnya berwarna putih kotor, bagian kepala berukuran besar berwarna kecoklatan, dan mandibula yang kecil, serta bagian ujung tubuh belakang yang meruncing. Panjang larva dewasa dapat mencapai $8 \mathrm{~cm}$ dan diameter $1-1,3 \mathrm{~cm}$.

\section{Pupa}

Berwarna coklat tua kemerah-merahan dan akan semakin berwarna gelap pada pupa dewasa. Pupa akan tertutup oleh benang-benang sutera yang dibentuk oleh larva dewasa sebelum berganti kulit menjadi tahapan pupa. Panjang pupa dewasa dapat mencapai $9 \mathrm{~cm}$, dan telah menunjukkan bagian-bagian calon sayap, kaki, antena dan mata.

\section{Imago}

$X$. ceramica mempunyai bentuk tubuh yang langsing dengan 2 pasang sayap (Gambar 1a). Umumnya, imago berwarna coklat kekuningan dengan sedikit warna hitam. Bagian tepi luar sayap depan dan sayap belakang memiliki corak berwarna hitam tipis dan bercak putih yang tidak beraturan. Sayap belakang sedikit tertutup oleh sayap depan. Panjang tubuhnya mencapai $70 \mathrm{~mm}$, sedangkan bentangan sayap yang dimiliki mencapai 100 mm. Imago jantan memiliki ukuran tubuh yang lebih kecil dibandingkan dengan imago betina.
Antena bertipe bipectinate dengan panjang dapat mencapai $1 \mathrm{~cm}$.

\section{Acalolepta rusticatrix}

Penggerek batang kedua adalah $A$. rusticatrix (Noerdjito, 2004), termasuk dalam bangsa Coleoptera, sebagai berikut (Borror et al., 2002):

Bangsa : Coleoptera

Suku : Cerambycidae

Species: Acalolepta rusticatrix

\section{Larva}

Larva-larva bangsa Coleoptera memiliki morfologi yang bervariasi (Lawrence, 1991), dan terdapat beberapa bagian yang dapat digunakan untuk membedakan dengan bangsa lain. Larva $A$. rusticatrix memiliki kepala berbentuk kapsul dan berkembang dengan baik serta mengalami skeletonisasi, terdapat 6 atau kurang stemmata pada setiap sisinya, tipe mulut penggigit pengunyah dengan mandibula yang kuat, memiliki kaki pada bagian dada dan tidak ditemukannya kaki pada bagian abdomen, serta pada tubuh larva dewasa umumnya memiliki 10 segmen dengan panjang dapat mencapai $3 \mathrm{~cm}$.

\section{Pupa}

Pupa bertipe Eksarat, berwarna coklat muda kekuning-kuningan dan akan menjadi coklat gelap pada saat akan menjadi imago. Pupa tipe ini pada saat dewasa kelihatan mengalami mummifikasi dan biasanya tidak tertutup oleh kokon. Panjang pupa dewasa dapat mencapai 3 $\mathrm{cm}$.

\section{Imago}

Imago A. rusticatrix (Gambar 1b) berbentuk mamanjang, bersisi sejajar dan biasanya agak silindris, dengan pronotum yang seringkali agak sempit dibandingkan dengan dasar elytra. Umumnya imago serangga anggota suku Cerambycidae memiliki antena yang sangat panjang (long-horned beetle) terdiri dari 11 segmen. Panjang antena imago jantan dapat mencapai 3 kali panjang tubuhnya, sedangkan antena betina umumnya memiliki panjang yang sama dengan tubuhnya.

Penelitian tentang tahapan perkembangan X. ceramica dilakukan Gotoh et al., (2003) di Malaysia menunjukkan hasil yang bervariasi 
mengikuti tempat tumbuh tanaman. Siklus hidup $X$. ceramica yang ditemui pada penelitian ini berbeda dengan yang terjadi di Myanmar dan Thailand (Eungwijarnpanya, 1994; Gotoh, 2002) dan hampir serupa dengan yang ditemui di Sabah, Malaysia (Gotoh et al., 2003). Penelitian Eungwijarnpanya (1994) melaporkan bahwa pada pertanaman jati di Myanmar dan Thailand, waktu antara fase larva dewasa dan imago dipisah berdasarkan musim pertumbuhan tanaman. Hal tersebut disebabkan adanya hubungan antara tahapan perkembangan serangga penggerek dan fenologi jati.

Pada compartment lain, hanya ditemukan lubang-lubang serangan pada batang disertai keluarnya kotoran segar yang mengindikasikan bahwa terdapat larva muda didalamnya. Lebih lanjut Gotoh et al., (2003) melaporkan bahwa terdapat perbedaan waktu terhadap fase $X$. ceramica pada tanaman jati di Thailand. Larva dewasa ditemukan pada bulan November, yaitu pada saat musim kering dimulai dan jati berhenti tumbuh. Sementara itu, serangga dewasa kebanyakan keluar pada bulan Maret sesaat sebelum memasuki musim penghujan yaitu waktu di mana jati memulai pertumbuhan. Koleksi A. rusticatrix menunjukkan bahwa, serangga ini ditemukan di semua compartment yang diamati dan dijumpai pada fase yang berbeda-beda, mulai dari larva muda sampai dengan stadium pupa. Seperti halnya $X$. ceramica, tidak menemukan telur A. rusticatrix di semua tempat lokasi pengamatan.

\section{Deskripsi Kerusakan}

Lubang gerekan yang dibuat oleh $X$. ceramica memiliki karakteristik berupa keluaran partikel kayu atau adanya rajutan benang halus menyerupai sutera (pada fase pupa atau prapupa) atau keberadaan pupa exuvia (tanda telah keluarnya imago). Pada penelitian ini, lubang yang menunjukkan tanda serangan disebut sebagai serangan baru sedangkan bekas lubang yang telah kering di katakan sebagai serangan lama.

Serangan A. rusticatrix diidentifikasi melalui keberadaan serpihan kayu yang lebih kasar dan kering di sekitar lubang gerekan. Tipe kerusakan oleh $A$. rusticatrix ini berbeda dengan kerusakan yang di sebabkan oleh $X$. ceramica. Tipe alat mulut pada fase larva kedua penggerek sama. Namun, perbedaan kekuatan mandibula yang dimiliki dapat mengakibatkan perbedaan lubang gerekan yang dibuat. Pengamatan terhadap perbedaan tipe kerusakan ini dapat digunakan sebagai identifikasi penggerek batang di lapangan. Kekuatan mandibula mulut yang berbeda berpengaruh kerusakan pada $G$. arborea.

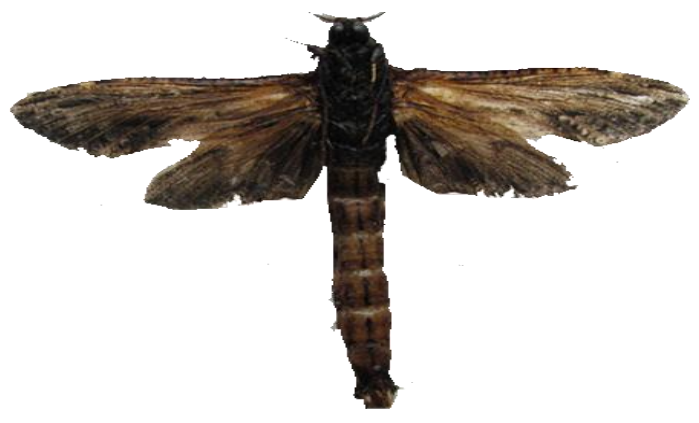

A

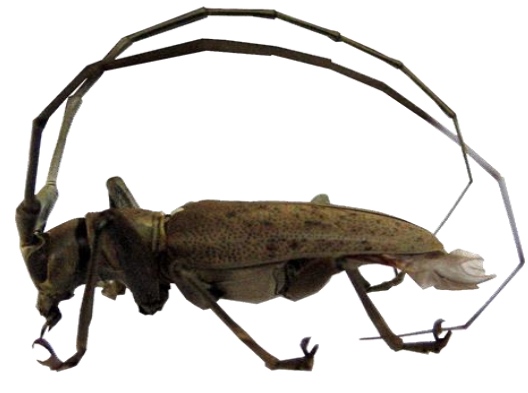

B

Gambar 1. Imago: a. Xyleutes ceramica, dan b. Acalolepta rusticatrix. Keterangan : $: 10 \mathrm{~mm}$ 
Tipe kerusakan yang diakibatkan $X$ ceramica berupa gerekan tunggal dengan kecenderungan arah gerekan ke batang pohon bagian atas. Berdasarkan hasil pengamatan, serangan larva menunjukkan sifat negatif geotaxis atau bergerak menuju ke arah tajuk inang, hal ini disebabkan larva akan mendapat keuntungan saat menuju ke arah tajuk, yaitu tersedianya bahan nutrisi dan bagian kayu yang lebih muda. Hasil penelitian menunjukkan bahwa, larva muda bergerak tegak lurus pada awal menggerek dan setelah mencapai bagian empulur berubah bergerak vertikal ke arah tajuk pohon. Gerekan yang dibuat mencapai panjang $30 \mathrm{~cm}$ dari lubang masuk, kemudian larva umumnyaakanberdiam pada bagian tersebut dan terus berkembang hingga fase prapupa, kemudian larva kembali bergerak turun menuju lubang masuk.

Pengembaraan larva berkaitan dengan pencarian nutrisi yang cukup pada batang. Oleh karena itu, dikatakan bahwa tempat yang cocok untuk pertumbuhan larva adalah kambium yang tumbuh aktif, dan selanjutnya dibatasi oleh kekerasan batang serta perubahan musim yang dapat memengaruhi aktivitas pertumbuhan. Halhal tersebut dapat mempengaruhi perilaku larva, waktu untuk menyelesaikan fase hidupnya, serta kemungkinan gerekan ke arah tajuk atau justru berlawanan. Hasil dari pengamatan terhadap perilaku saat oviposition dapat membantu dalam menjelaskan karakteristik dari serangan $X$. ceramica seperti yang disebutkan di atas. Diperlukan data yang lebih lengkap dan detail mengenai lokasi oviposition pada umur tanaman inang yang berbeda agar dapat dipahami secara lengkap mengenai strategi oviposition $X$. ceramica kaitannya dengan pertumbuhan pohon.

Tipekerusakan yangberbedaditunjukkan $A$. rusticatrix. Pengerek ini menggerek batang kayu, kemudian berdiam diri pada bagian subcortical sampai dengan masa pupa dan akhirnya keluar imago dapat dari lubang yang berbeda. Larva $X$. ceramica menggerek sampai bagian empulur, menghabiskan fase hidupnya pada bagian empulur hingga memasuki masa prapupa dan pupa, larva akan turun menuju lubang masuk, sampai akhirnya keluar imago dengan meninggalkan pupa exuvia pada lubang yang sama. Kerusakan yang diakibatkan pada batang kayu $G$. arborea berbeda berdasarkan cara menyerang kedua jenis serangga penggerek (Gambar 2a dan b).

Jaringan pada kayu pohon inang bervariasi dalam hal kualitas untuk serangga penggerek (Hosking dan Hutcheson, 1979). Lebih lanjut, Haack dan Slansky (1987) menyebutkan bahwa perbedaan kandungan nutrisi pada beberapa bagian tanaman yaitu: (a) batang (bark) umumnya memiliki kandungan nutrisi yang rendah (khususnya karbohidrat dan nitrogen); (b) zona subcortical pada jaringan (batang bagian dalam, kambium, serta immature xylem) memiliki konsentrasi nutrisi beberapa kali lebih tinggi; (c) bagian sapwood yang tebal memiliki nutrisi dengan konsetrasi yang rendah; (d) bagian heartwood memiliki kualitas nutrisi yang rendah; dan (e) pada bagian inti kadang memiliki konsentrasi nutrisi nitrogen lebih tinggi dibandingkan bagian heartwood.

\section{Intensitas Serangan (IS) dan Luas Serangan (LS)}

Kedua jenis penggerek batang menunjukkan kecenderungan serangan yang berbeda (Tabel 3 dan 4). Luas serangan dan intensitas serangan $X$. ceramica tertinggi berturut-turut $22 \%$ dan $13 \%$ ditemui pada compartment 26A Zone 7, sedangkan serangan hama $A$. rusticatrix berturut-turut $64,4 \%$ dan $54,8 \%$ ditemui pada compartment 25B Zone 7. Compartment 26A Zone 7 merupakan pertanaman $G$. arborea usia 2 tahun dengan ukuran diameter maksimal 11,97 $\pm 3,22 \mathrm{~cm}$. Karakteristik kayu $G$. arborea muda dengan tingkat kekerasan yang masih rendah (Gunawan et al., 2001), berpengaruh terhadap tingkat serangan $X$. ceramica menjadi lebih tinggi. Keberadaan serangan penggerek batang ditemui berbeda berdasarkan faktor umur, yakni $A$. rusticatrix ditemukan di semua tingkat umur tanaman $G$. arborea yang diamati, sedangkan serangan $X$. ceramica hanaya dijumpai pada usia 2 dan 3 tahun. Sofyan dan Islam (2007) menyebutkan bahwa umumnya pertambahan umur tanaman dibarengi dengan pertumbuhan tinggi dan diameter tanaman tersebut. Lebih lanjut Dwianto dan Marsoem (2008) menjelaskan, bahwa perubahan sifat fisik maupun mekanik kayu dapat dipengaruhi oleh faktor-faktor alam berupa : (1) jenis kayu; (2) umur dan tempat tumbuh; (3) letak dalam 
batang; (4) diameter; (5) kelembaban, kadar air dan suhu; (6) cuaca dan jamur; serta (7) kebakaran hutan.

Penelitian terhadap kayu G. arborea usia 2 tahun dan 6 tahun yang dilakukan Gunawan et al., (2001) menunjukkan hasil bahwa, tingkat kepercayaan $5 \%$ umur tanaman dan lokasi tempat tumbuh memberikan perbedaan nyata terhadap sifat keteguhan geser dan kekerasan kayu. $G$. arborea umur 2 tahun, memiliki tingkat keteguhan geser dan kekerasan yang lebih rendah dibandingkan $G$. arborea usia 6 tahun. Perbedaan ukuran diameter pada tanaman $G$. arborea yang diamati berpengaruh terhadap keberadaan serta tingkat serangan tiap-tiap penggerek batang.

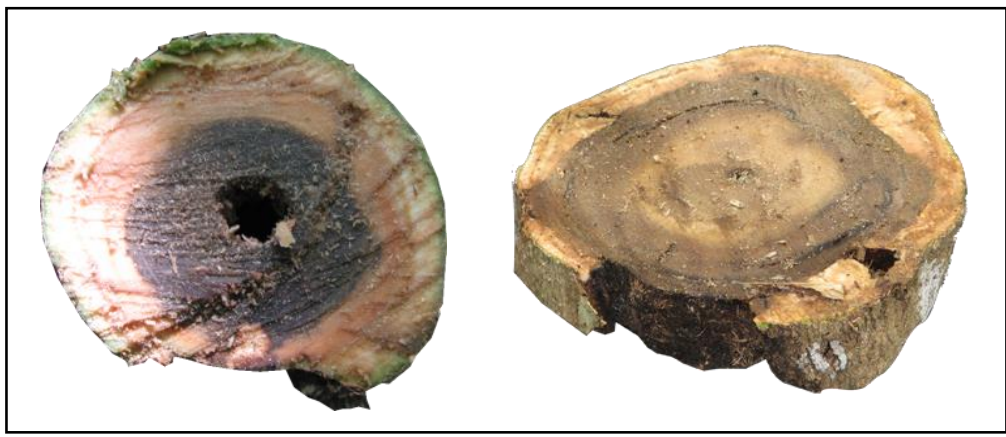

Gambar 2. Kerusakan kayu.

A. akibat Xyleutes ceramica; B. akibat Acalolepta rusticatrix.

Tabel 3. Keberadaan serangan Xyleutes ceramica pada tegakan Gmelina arborea.

\begin{tabular}{lccccc}
\hline \hline \multicolumn{1}{c}{ Compartment } & Umur (tahun) & Luas Serangan & Intensitas & \multicolumn{2}{c}{ Rerata pohon terserang (\%) } \\
\cline { 5 - 6 } & & 22 & Serangan (\%) & Serangan baru & Serangan lama \\
\hline \hline 26A Zone 7 & 2 & 15 & 13 & 30 & 50 \\
24A Zone 7 & 2 & 10 & 9,8 & 24 & 47 \\
04C Zone 16 & 3 & 14 & 8 & 36 & 37 \\
27A Zone 12 & 3 & 0 & 0 & 23 & 48 \\
04A Zone 12 & 5 & 0 & 0 & 0 & 0 \\
25B Zone 7 & 7 & &
\end{tabular}

Tabel 4. Keberadaan serangan Acalolepta rusticatrix pada tegakan Gmelina arborea.

\begin{tabular}{lccccc}
\hline \hline Compartment & Umur (tahun) & Luas Serangan & Intensitas & \multicolumn{2}{c}{ Rerata pohon terserang (\%) } \\
\cline { 5 - 6 } & & & Serangan (\%) & Serangan baru & Serangan lama \\
\hline \hline 26A Zone 7 & 2 & 10,3 & 6,3 & 37 & 45 \\
24A Zone 7 & 2 & 10,4 & 7,6 & 28 & 34 \\
04C Zone 16 & 3 & 17 & 12 & 27 & 31 \\
27A Zone 12 & 3 & 12,2 & 10 & 40 & 33 \\
04A Zone 12 & 5 & 42,2 & 31,7 & 6 & 31 \\
25B Zone 7 & 7 & 64,4 & 54,8 & 26 & 43 \\
\hline \hline
\end{tabular}

\section{Simpulan dan Saran}

\section{Simpulan}

Hama penggerek batang yang ditemukan terdiri dari $X$. ceramica dan A. rusticatrix dengan kecenderungan serangan yang berbeda. $X$. ceramica cenderung menyerang pada tanaman G. arborea usia muda yakni usia 2 dan 3 tahun, sedangkan A. rusticatrix dapat menyerang sampai dengan usia tanaman 7 tahun. Tindakan monitoring dalam rangka pengendalian populasi serangga idealnya dimulai pada usia tanaman 2 tahun, karena pada usia tersebut telah mulai terserang penggerek batang baik $X$. ceramica maupun A. rusticatrix.

\section{Saran}

Dari hasil penelitian ini, penulis menyarankan agar dilakukan penelitian lebih 
lanjut mengenai pengaruh faktor lingkungan terhadap keberadaan penggerek batang dengan kisaran perbedaan yang lebih lebar. Peran musuh alami sebagai sebagai salah satu cara pengendalian penggerek batang perlu mulai dikaji. Di masa yang akan datang pengamatanpengamatan secara seri untuk memperoleh data tentang periode rawan dari tanaman $G$. arborea terhadap kerusakan akibat kedua jenis penggerek batang.

\section{Ucapan Terima Kasih}

Penulis mengucapkan terima kasih kepada PT. Sumalindo yang telah mendanai serta menyediakan fasilitas hingga dapat terselesaikannya penelitian ini.

\section{Daftar Pustaka}

Beeson, C.F.C. 1941. The Ecology and Control of The Forest Insects of India and The Neighboring Countries. Government Printing Office. pp.767-768. India.

Borror, D.J., Johnson, N.F. dan Triplehorn, C.A. 2002. An Introduction to the Study of Insects, $5^{\text {th }}$ Edition. Saunders College Publishing. Philadelphia.

Burgess, T. dan Wingfield, M.J. 2002a. Impact of Fungal Pathogens in Natural Forest Ecosystems: A Focus on Eucalyptus. In: Sivasithamparam, K. and Dixon, K.W. (Eds). Microorganisms in Plant Conservation and Biodiversity. pp. 285306. K1uwer Academic Publishers. Netherlands.

Burgess, T. dan Wingfie1d, M.J. 2002b. Quarantine is Important in Restricting the Spread of Exotic Seedborne Tree Pathogens in the Southern Hemisphere. Int. For. Rev. 4: 65-65.

Dvorak, W.S. dan Hodge, G.R. 1998. Wood Supply Strategies in Countries with Fast-Growing Plantations. Paper Age (March): 25-27.

Dwianto, W. dan Marsoem, S.N. 2008. Tinjauan Hasil-hasil Penelitian Faktor-faktor Alam yang Mempengaruhi Sifat Fisik dan Mekanik Kayu Indonesia. J. Ilmu dan Teknologi Kayu Tropis, 5 (2): 85-100.

Eungwijarnpanya, S. 1994. Bionomics of Teak Beehole Borer (Xyleutes ceramicus) in Northern Thailand: Emergence and Response to Light Trap of Adult Moth. Thailand. J. Agricultural Science, 27: 1-8.
Eungwijarnpanya, Gotoh, T., Supachote, Yincharoen, S., Choldumrongkul, S., Nakamuta, K., Pholwicha, P., Piananurak, P. dan Hutacharern, C. 2007. Emergence, Oviposition and Larval Behaviors in The Teak Beehole Borer (Xyleutes ceramica wlk.) In Northern Thailand (Lepidoptera: Cossidae). Japan Agricultural Research Quarterly, 41 (4): 307-314.

Gotoh, T. 2002. Strategies for The Management of The Teak Beehole Borer, Xyleutes ceramicus (Walker) (Lepidoptera: Cossidae) in Thailand. In Proceedings of the IUFRO/FAO Workshop on Pest Management in Tropical Forest Plantations, Chanthaburi, Thailand, FORSPA Publication No. 30: 99-103.

Gotoh, T., James, R.K. dan Matsumoto, K. 2003. Stem Borers of Teak and Yemane in Sabah, Malaysia, with Analysis of Attacks by the Teak Beehole Borer (Xyleutes ceramica Wlk.). Japan Agricultural Research Quarterly, 37 (4): 253-261.

Gunawan, R.H.R., Dodi, I.F. dan Iskandar, A. 2001. Variasi Sifat Kayu HTI karena Umur dan Lokasi Tanaman. Pros. Sem. Nasional IV Mapeki. pp II41-II50. Samarinda.

Haack, R.A. dan Slansky, F.Jr. 1987. Nutritional Ecology of Wood-Feeding Coleoptera, Lepidoptera, and Hymenoptera. In: F Slansky Jr, J.G. (Eds.). Rodriguez Nutritional Ecology of Insects, Mites, Spiders, and Related Invertebrates, pp. 449-85. New York.

Hanks, L.M. 1999. Influence of the Larval Host Plant on Reproductive Strategies of Cerambycid Beetles. Annual Review Entomology, 44: 483-505.

Higgins, S.I., Richardson, D.M. dan Cowling, R.M. 1996. Modeling Invasive Plant Spread: The Role of Plant-Environment Interactions and Model Structure. Ecology, 77: 2043-2054.

Hosking, G.P. dan Hutcheson, J.A. 1979. Nutritional Basis for Feeding Zone Preference of Arhopalus Ferus (Coleoptera: Cerambycidae). New Zealand J. Forest Science, 9: 185-92.

Huang, J. 1991. Current Status and Problems in The Control of Poplar Wood-Boring Insect Pests. $J$. Forest Disease and Insect Pests, 1: 52-56.

Mathew, G. 1986. Insects Associated with Forest Plantation of Gmelina arborea Roxb. in Kerala, India. Indian J. For, 9: 308-312.

McMaugh, T. 2007. Pedoman Surveilensi Organisme Pengganggu Tumbuhan di Asia dan Pasifik. (Terj.) Andi Trisyono. ACIAR Monograph. 119a. 192p.

Meffe, G.K. dan Carroll, C.R. 1997. Principles of Conservation Biology. Sinauer Associates, Sunderland, Massachussets. 
Nair, K.S.S. 1982. Seasonal Incidence, Host Range and Control of The Teak Sapling Borer, Sahysdrassus malabaricus. Kerala Forest Research Institute, India, KFRI Research Report No. 16. 36p.

Nair, K.S.S. dan Mathew, G. 1988. Biology and Control of Insect Pests of Fast-Growing Hardwood Species. 1. Albizzia falcataria and Gmelina arborea. KFRI Research Report No. 51. Kerala Forest Research Institute Peechi, India, 8p.

Noerdjito, W.A. 2004. Longicorn Beetles from Gunung Halimun National Park, West Java, Indonesia from 1997-2002. Research Material. Bull. of The Forestry and Forest Products Research Institute, 1-3: 384.

Rachmatsyah, O. dan Haneda, N.F. 1998. Jenis-Jenis Serangga Hama Potensial pada Hutan Tanaman di Indonesia (Kinds of potential pests in Indonesian plantation forest). In: Suratmo, F.G., Hadi, S., Husaeni, E.A., Rachmatsjah, O., Kasno, Nuhamara, S.T. and Haneda, N.F. (Eds.). Proceedings Workshop Permasalahan dan Strategi Pengelolaan Hama di Areal Hutan Tanaman, 167-170. Fakultas Kehutanan IPB dan Departemen Kehutanan, Bogor, Indonesia. Workshop Permasalahan dan Strategi Pengelolaan Hama di Areal Hutan Tanaman, 167-170. Fakultas Kehutanan IPB dan Departemen Kehutanan, Bogor, Indonesia.

Smith, M.T., Bancroft, J., Gao, R. dan Li, G. 1985 Dispersal Potential of Anoplophora glabripennis Motsch. Poplars. ACTA Ecol. Sin, 18: 269-277.
Sofyan, A. dan Islam, S. 2006. Pertumbuhan Bibit Mersawa pada Berbagai Tingkat Umur Semai. Makalah Penunjang pada Ekspose Hasil-hasil Penelitian: Konservasi dan Rehabilitasi Sumberdaya Hutan. Padang.

Suhaendi, H. dan Djapilus, A. 1979. Hasil Pendahuluan Mengenai Perkecambahan dan Pertumbuhan Gmelina arborea L. Danish/FAO di Persemaian. Lembaga Penelitian Hutan. Bogor.

Wingfield, M.J. dan Robison, D.J. 2004. Disease and Insect Pest of Gmelina arbórea: Real Threats and Real Opportunities. New Forest, 28: 227-243. 